\title{
ANALYSIS OF SUSTAINABLE PRODUCTION PRACTICES IMPLEMENTED BY CAR MANUFACTURERS
}

doi:10.2478/mape-2018-0105

Date of submission of the article to the Editor: 05/2018 Date of acceptance of the article by the Editor: 07/2018

MAPE 2018, volume 1, issue 1, pp. 837-843

Dr hab. inż. Patrycja Hąbek, Prof. PŚ.

Silesian University of Technology, Poland

Juan Jose LAVIOS VILLAHOZ,

Universidad de Burgos, Spain

\begin{abstract}
Companies are increasingly implementing sustainable solutions as they face a growing sustainability demands from different stakeholders. The question is whether car manufacturers adhered to sustainable production principles and at what level they are doing it in practice.

The Lowell Center for Sustainable Production (LCSP) is used as a model to analyse the main aspects of sustainable production and assess the companies in the automotive sector in European Union. The data was collected from the Corporate Social Responsibility/ Sustainability reports of the individual car manufacturers found in the online data base of Global Reporting Initiative. Empirical evidence shows the adherence of these companies to the LCSP sustainable production principles. All the studied companies seem to be conscious of the significance of sustainability for the automotive industry. Although most of the sustainable production practices are focused on the environmental dimension of sustainability, employee and social aspects are not ignored in the reports.
\end{abstract}

Keywords: sustainability, automotive industry, sustainability reports, sustainability production principles

\section{INTRODUCTION}

The development of industry implies the progress of civilization and increases people standard of living. On the other hand, industry is the main consumer of natural resources and producer of toxic by-products and waste. As a result stakeholders of industrial enterprises are progressively paying more attention not only on production costs but also to the overall influence that these enterprises have in society: customers are becoming more and more interested in the environmental impact of the products they decide to buy and, governmental institutions and communities are gradually emphasizing the importance of corporate social responsibility (Kołodziej and Maruszewska, 2015). Manufacturers are increasingly being conscious of their impact on environment and society as well as of their potential contribution to achieving sustainable development goals (Kleindorfer et al., 2005; Bluszcz, 2017, JonekKowalska, 2017). All these facts highlight the importance of considering sustainability from an operational perspective, and understanding the way in which sustainable production might be attained within manufacturing organizations. Companies, having to face increasing regulation, intensifying stakeholder demands, and a highly dynamic market. Companies have begun to address ecological and social issues in different ways (Molenda and Ratman-Kłosińska 2018; Midor, 2014) specifically, in automotive industry increasing regulatory demands can be observed, such as the reduction of $\mathrm{CO}_{2}$ emissions which is a motivation for the car manufacturers to take into account sustainable production practices in their daily operations. There are many more challenges in the automotive industry related to attaining sustainable success at the market. The car manufacturers may deal with many different expectations of their stakeholders. Political agents, society and customers require more eco-friendly cars, alternative power trains or new mobility concepts. Employees demand healthy and safety 
workplaces, opportunities for development and at the same time local communities demand socially responsible behaviour and activities that will address local problems.

The sustainable production practices are implemented in different dimensions and scope, usually environmental. Thus, there is a need to highlight the importance of the human factor in the production process, and the impact of the processes on the local communities when considering sustainable practices. The research question posed in the paper is: If and at what level car manufacturers adhere to sustainable production principles in their current practices? The rest of the paper is structured as follows. The next section provides an overview of sustainable production concept and discusses its principles. This is followed by a section dedicated to the methodology used in the research process. Finally, the research findings are presented and the paper ends with conclusions.

\section{SUSTAINABLE PRODUCTION}

Sustainable manufacturing practices have been defined mostly from an environmental perspective, aiming at minimizing the impacts of manufacturing operations on the environment while optimizing the production efficiency of the company (Nordin et al., 2014). The most common environmental sustainability practices used among large companies are eco-design, renewable energy usage, energy and material optimization, recycling, product life cycle and end of life-cycle management, and waste minimization (Hurreeram et al., 2014). We can often encounter a misinterpretation of the concept of sustainable production/manufacturing and the limitation of practices in this field to the so-called "green manufacturing" while the term "green manufacturing" usually refers to production characterized by reducing energy consumption per unit of production, using materials from recycling or limiting the amount of waste generated. However, having in mind that sustainability should be defined through its three dimensions economic, environmental and social in this paper sustainable production practices is understood as the actions, initiatives and techniques that positively affect the environmental, social or economic performance of a firm (Alay et al., 2017). The Lowell Center for Sustainable Production (LCSP) (1998) defines sustainable production as "the creation of goods and services using processes and systems that are non-polluting; conserving of energy and natural resources; economically viable; safe and healthful for employees, communities and consumers; and socially and creatively rewarding for all working people". If we talk about sustainable production, we need to analyze the production process that takes into account all three dimensions of sustainable development - economic, social and environmental.

The LCSP principles reflect the main aspects of sustainable production. Principle 1 concerning the design of products, services and packaging taking into account life cycle thinking, product efficiency, durability and ease of recycling, environmental and user-friendly product characteristics. Principle 2 focuses on the reduction or elimination of waste, redesigning of components to reduce solid waste. Principle 3 involves issues connected with energy and materials reduction, using non-renewable resources, water consumption, and material usage that is safe for the environment, workers and customers. Principle 4 focuses on hazardous emissions into air and water, and hazardous physical agents, technologies or work practices. Principles 5, 7 and 8 address different aspects related to employees. Principle 5 is focused on the reduction of the risks workers are exposed to, principle 7 concerns practices aiming to increase employee participation in sustainable production via for example employee improvement suggestions, creativity, and reward systems. Principle 8 concerns practices seeking to provide opportunities for employee advancement, job satisfaction, training, gender equality, career development. The principle 6 encompasses economic performance issues aimed at putting sustainability goals into company strategy, regular communication with employees, increasing customer satisfaction, reducing environmental, health and safety compliance costs and continuous evaluation and improvement, focused on the long-term economic performance. The principle 9 deals with community development issues and encompasses such practices as creating job opportunities for local community, partnerships 
with local authorities, educational institutions, volunteering work and sponsorships activities. The scope of issues covered under these principles clearly indicates that in order to make the manufacturing process more sustainable, improvements in the enterprise should concern not only products or technological processes but also the working conditions and well-being of the community, taking into account the product life-cycle perspective.

The automotive industry plays a significant role in today's economy, both in shaping capital and in creating new technologies and jobs. No less important are the companies in the automotive sector in contemporary ecological problems. Caring for the natural environment and striving for sustainable development has become the biggest challenge for these companies. Therefore, the intention of the authors of this paper was to present an outlook of how car manufacturers carry out sustainability production practices.

\section{METHODOLOGY}

This exploratory study does not attempt to draw a statistical generalization from the results, but to present empirical evidence of implementation of the LCSP sustainable production principles through practices in the automotive sector in European Union. The data was collected from the Corporate Social Responsibility/ Sustainability reports of the individual car manufacturers found in the online data base of Global Reporting Initiative. After preliminary analysis for the study, reports of seven car manufacturers, which published CSR/Sustainability reports in English in 2017, were selected. The report of Jaguar Land Rover was excluded from the study as it contains 25 pages in comparison to an average of 150 of the other reporting companies. The study concentrates on one sector to analyse the sustainable production practices of manufacturers dealing with comparable sustainability challenges. All the assessed reports were prepared according to the same internationally recognized reporting standard of Global Reporting Initiative - GRI version G4 (Hąbek and Brodny, 2017).

The reports of the selected car manufacturers were used to obtain information on sustainable production practices. The Lowell Center for Sustainable Production (LCSP) sustainable production principles (Veleva and Ellenbecker, 2001) were used as a criteria for reports evaluation. The nine criteria and some example practices related to each of them are presented in Table 1.

\section{Table 1}

The LCSP principles of sustainable production and exemplary practices

\begin{tabular}{|c|c|}
\hline $\begin{array}{l}\text { The LCSP Principles of } \\
\text { Sustainable Production }\end{array}$ & Examples of Practices \\
\hline $\begin{array}{l}\text { 1. Products and packaging are } \\
\text { designed to be safe and } \\
\text { ecologically sound through their } \\
\text { life cycles; services are } \\
\text { designed to be safe and } \\
\text { ecologically sound. }\end{array}$ & $\begin{array}{l}\text { Material usage according to REACH and ROHS in processes and products } \\
\text { Considerations regarding disassembly, reuse and recycling during product } \\
\text { design } \\
\text { Eco-design assisted by customers } \\
\text { Recyclability and reuse of incoming materials packaging } \\
\text { Packaging minimization } \\
\text { Design for the environment (DfE) }\end{array}$ \\
\hline $\begin{array}{l}2 \text { Wastes and ecologically } \\
\text { incompatible by-products are } \\
\text { reduced, eliminated or recycled. }\end{array}$ & $\begin{array}{l}\text { Redesigning of components to reduce solid waste } \\
\text { Non-conforming products reduction } \\
\text { Reuse and recycle of direct and indirect waste } \\
\text { Employee training on sorting and waste reduction } \\
\text { Process water and emulsions close loop systems } \\
\text { External and on-site recycling } \\
\text { Biological process for processing waste waters } \\
\text { Donation of waste and by-products to other industries or institutions }\end{array}$ \\
\hline
\end{tabular}




\begin{tabular}{|c|c|}
\hline $\begin{array}{l}3 \text { Energy and materials are } \\
\text { conserved, and the forms of } \\
\text { energy and materials used are } \\
\text { most appropriate for the desired } \\
\text { ends. }\end{array}$ & $\begin{array}{l}\text { Employee training on energy savings } \\
\text { Renewable energy } \\
\text { Preventive equipment maintenance } \\
\text { Energy-efficient building automation systems } \\
\text { Energy audits } \\
\text { Material recycle and reuse } \\
\text { Material substitution for better efficiency } \\
\text { Material usage optimization } \\
\text { Monitor fresh water use } \\
\text { Recirculating water for cooling } \\
\text { Close loop water systems }\end{array}$ \\
\hline $\begin{array}{l}4 \text { Chemical substances or } \\
\text { physical agents and conditions } \\
\text { that present hazards to human } \\
\text { health or the environment are } \\
\text { eliminated }\end{array}$ & $\begin{array}{l}\text { Hazardous substances substitution or elimination in processes } \\
\text { Tracking chemicals in processes and products } \\
\text { Materials usage according to REACH and ROHS in processes and products } \\
\text { Training on hazardous substances } \\
\text { Solvents substitution } \\
\text { Air filtration and cleaning systems } \\
\text { Heavy metals filtration } \\
\text { Biological based wastewater treatment } \\
\text { Standard safety procedures }\end{array}$ \\
\hline $\begin{array}{l}5 \text { Work places and technologies } \\
\text { are designed to minimize or } \\
\text { eliminate chemical, ergonomic } \\
\text { and physical hazards. }\end{array}$ & $\begin{array}{l}\text { Robotic automation in hazardous activities } \\
\text { Internal safety inspections } \\
\text { External work environment audits } \\
\text { Employees rotation among work stations } \\
\text { Process modifications to reduce noise and vibrations } \\
\text { Employee training on hazardous risks }\end{array}$ \\
\hline $\begin{array}{l}6 \text { Management is committed to } \\
\text { an open, participatory process } \\
\text { of continuous evaluation and } \\
\text { improvement, focused on the } \\
\text { long-term economic } \\
\text { performance of the firm. }\end{array}$ & $\begin{array}{l}\text { Strategic sustainability and functional goals display throughout the plant } \\
\text { Technology investments prioritization considering environment, safety, } \\
\text { quality and economic aspects } \\
\text { Communicating employees about strategic plans, targets and results } \\
\text { ISO } 9001 \text { for managerial continuously evaluation }\end{array}$ \\
\hline $\begin{array}{l}7 \text { Work is organized to conserve } \\
\text { and enhance the efficiency and } \\
\text { creativity of employees. }\end{array}$ & $\begin{array}{l}\text { Work standardization } \\
\text { Work accountability } \\
\text { Employee improvement suggestions goals } \\
\text { Rewards for applicable improvement suggestions from employees } \\
\text { Team work } \\
\text { Improvement meetings }\end{array}$ \\
\hline $\begin{array}{l}8 \text { The security and wellbeing of } \\
\text { all employees is a priority, as is } \\
\text { the continuous development of } \\
\text { their talents and capacities. }\end{array}$ & $\begin{array}{l}\text { Health and safety management system } \\
\text { Training plans } \\
\text { Career development programs } \\
\text { Employee rotation } \\
\text { Scholarships } \\
\text { Subsides for health and wellbeing purposes } \\
\text { Job satisfaction assessment } \\
\text { Performance appraisal }\end{array}$ \\
\hline $\begin{array}{l}9 \text { The communities around } \\
\text { workplaces are respected and } \\
\text { enhanced economically, } \\
\text { socially, culturally and } \\
\text { physically; equity and fairness } \\
\text { are promoted. }\end{array}$ & $\begin{array}{l}\text { Job opportunities for locals } \\
\text { Collaborations with educational institutions } \\
\text { Periodical meetings with local authorities } \\
\text { Volunteering work within local communities } \\
\text { Sponsoring local initiatives, associations }\end{array}$ \\
\hline
\end{tabular}

Source: based on (Alay et al., 2017).

The content analysis of CSR/Sustainability reports was done according to the same criteria as the LCSP principles of sustainable production. The level of fulfilment of each criterion was assessed using the scale presented in Table 2. 
Table 2

The level of fulfilment of the principles of sustainable production

\begin{tabular}{|l|c|}
\hline Information about one practice of SP included in the report & + \\
\hline Information about two practices of SP included in the report & ++ \\
\hline Information about three or more practices of SP included in the report & +++ \\
\hline
\end{tabular}

Methodological limitations must be considered when evaluating the findings. The analysis relies on information published in CSR/sustainability reports by the companies themselves, leaving room for bias. It must be noted here that, for the purpose of the study, the companies were assessed in terms of how they communicate sustainable production practices rather than what they are actually doing.

\section{RESULTS}

Most of the analysed documents were separate sustainability/CSR reports. Only two out of seven reports were annual reports with a section dedicated to sustainability issues. According to the information disclosed in the analysed reports, all car manufacturers are practicing all of the sustainable production principles (see Table 3). Although, most of the sustainable production practices are focused on the environmental dimension of sustainability, all car manufacturers present in the report information a minimum of two practices in this realm, employee and social aspects are not ignored in the reports.

Table 3

The level of fulfilment of the principles of sustainable production of analysed car manufacturers (+++ high level, ++ medium, + low level)

\begin{tabular}{|l|c|c|c|c|c|c|c|c|c|}
\hline \multicolumn{1}{|l|}{ Principles of Sustainable Production } & $\mathbf{1}$ & $\mathbf{2}$ & $\mathbf{3}$ & $\mathbf{4}$ & $\mathbf{5}$ & $\mathbf{6}$ & $\mathbf{7}$ & $\mathbf{8}$ & $\mathbf{9}$ \\
\hline $\begin{array}{l}\text { BMW Group } \\
\text { Sustainable Value report 2016 }\end{array}$ & +++ & +++ & +++ & +++ & +++ & +++ & +++ & +++ & +++ \\
\hline $\begin{array}{l}\text { Daimler } \\
\text { Sustainability report 2016 }\end{array}$ & +++ & ++ & +++ & +++ & +++ & ++ & + & +++ & +++ \\
\hline $\begin{array}{l}\text { Fiat Chrysler Automobiles } \\
\text { Sustainability report 2016 }\end{array}$ & +++ & +++ & +++ & +++ & +++ & +++ & +++ & +++ & +++ \\
\hline $\begin{array}{l}\text { Renault } \\
\text { Annual Financial Report 2016 }\end{array}$ & +++ & +++ & +++ & +++ & ++ & ++ & ++ & +++ & +++ \\
\hline $\begin{array}{l}\text { PSA } \\
\text { Corporate Social Responsibility report } \\
2016\end{array}$ & +++ & +++ & ++ & +++ & +++ & +++ & ++ & ++ & ++ \\
\hline $\begin{array}{l}\text { Volvo Car } \\
\text { Annual and sustainability report 2016 }\end{array}$ & ++ & +++ & +++ & +++ & ++ & +++ & +++ & +++ & +++ \\
\hline VW Sustainability Report 2016 & +++ & +++ & +++ & +++ & ++ & +++ & ++ & +++ & +++ \\
\hline
\end{tabular}

The practices are oriented on design of environmentally friendly cars, life cycle thinking, using green materials and taking into account assumptions of circular economy. In this area worth highlighting are practices of using design for recycling (for example BMW Group) or design for the circular economy (for example Fiat Chrysler Automobiles, FCA). A research center of FCA (CRF) has been taking part in several new Horizon 2020 publicly-funded collaborative research projects, such as Circ-Pack focused on a circular economy approach for recycling of production scraps, Plasti-Circle focused on a circular economy approach for recycling plastic packaging waste and Ecobulk for the development of a recycling process of natural fiber reinforced plastics.

Sustainable production practices in the realm of human resources of the studied companies are oriented towards implementing occupational health and safety systems, employee training 
on hazardous risks as well as different activities concerning the wellbeing of the employees e.g. career development programmes and job satisfaction assessment. In this area, interesting practice is disclosed by BMW Group which rely on rewarding sustainable business performance. The Supervisory Board decides on the level of compensation received by members of the Board of directors, orienting its decisions on the sustainable development of the BMW Group. Volkswagen, for example,, is taking care of the ergonomics at the workstation from the earliest planning and design stages of new vehicle models. "Ergo assistants" give employees advice directly at their workstations on how they can optimize workflows from an ergonomic point of view. While Volvo Group has internally run best practice health and safety awards.

Issues related to community development concentrate on sponsorships activities often conducted through car manufacturer foundation, collaboration with educational institutions or corporate volunteering actions.

When it comes to management issues sustainability aspects are incorporated into strategies of all analysed companies. Continuous development, improvement is assured via quality management systems among others and communication with employees is conducted as a part of stakeholder dialogue.

\section{CONCLUSIONS}

Companies are increasingly implementing sustainable solutions as they face a growing sustainability demands from different stakeholders. The question the authors have posed at the beginning is If and at what level car manufacturers adhere to sustainable production principles in their current practices?

This paper presented empirical evidence of adherence to the LCSP sustainable production principles through practices of car manufacturers. All companies seem to be well-aware of the significance of sustainability for the automotive industry. The greatest number of practices were found in sustainable production principles focused on preserving the natural environment by using life cycle thinking when designing products, conserving energy and materials, waste management and managing hazardous substances. Fewer practices were disclosed in the area of enhancing the efficiency and creativity of employees and such designing of work places and technologies as to minimize or eliminate chemical, ergonomic and physical hazards.

When referring to the results obtained, we must remember that in the analysis only CSR/Sustainability reports were used. Therefore, the research results presented in the paper present practices of sustainable production that are communicated by producers. Thus the information disclosed in the reports may not necessarily refer to real practices or results achieved in this area as it was evidenced by recent scandals involving car manufacturers, for example, Volkswagen which was accused of illegally using "cheat devices" to falsify emissions data on its diesel vehicles, pretending they were cleaner than they are when used on the road. It might be concluded that the number and variety of activities undertaken by the studied companies are promising as long as these reports reflect real, everyday practices.

\section{ACKNOWLEDGEMENTS}

This paper is the result of research conducted at the Institute of Production Engineering, Faculty of Organization and Management, Silesian University of Technology, within the statutory work entitled „Development of intelligent production methods as well as work and life environments in the context of production engineering challenges". Research reference number 13/030/BK_18/0039. 


\section{REFERENCES}

Alay, C., Säfsten, K. and Johansson, G. (2017). Conceptual sustainable production principles in practice: Do they reflect what companies do?, Journal of Cleaner Production 141 pp. 693-701.

Bluszcz, A. (2017). Ecological Growth Boundaries. Management Systems In Production Engineering, Volume: 25, Issue: 1, pp. 55-59.

Hąbek, P. and Brodny, J. (2017). Corporate Social Responsibility Report - An Important Tool to Communicate with Stakeholders. In 4th International Multidisciplinary Scientific Conference on Social Sciences and Arts. Albena, Bulgaria, pp. 241-248.

Hurreeram, D.K., Bhoomitra, T. and Devkumar, C. (2014). An assessment of sustainable manufacturing practices in Mauritius. In: International Conference on Sustainable Design and Manufacturing SDM, Paper sdm14-040, pp.230-242.

Jonek-Kowalska, I. (2017). Environmental Costs of Mining Production in the Perspective of The Mine Lifecycle. 4th BECI International Conference on Business and Economics 2017, Book Series: European Proceedings of Multidisciplinary Sciences, Volume: 1, 2017, pp. 80-90.

Kleindorfer, P.K., Singhal, K. and Van Wassenhove, L.N. (2005). Sustainable operations management. Prod. Oper. Manag. 14, pp. 482-492.

Kołodziej, S. and Maruszewska, E.W. (2015). Economical Effectiveness and Social Objectives in Corporate Social Reports - A Survey Among Polish Publicly Traded Companies. In: 2nd International Multidisciplinary Scientific Conferences on Social Sciences and Arts. Albena, Bulgaria, pp. 161-167.

Lowell Center for Sustainable Production (LCSP), Sustainable Production definition, https://www.uml.edu/Research/Lowell-Center/About/Sustainable-Production-Defined.aspx, [Accessed 30 Mar. 2018]

Midor, K. (2014). Innovations in the Field of Enterprise Quality Management as an Element of Sustainable Development Implementation. Conference: 14th International Multidisciplinary Scientific Geoconference (SGEM) Location: Albena, Bulgaria, Jun 17-26, Geoconference on Ecology, Economics, Education and Legislation, SGEM 2014, Vol III Book Series: International Multidisciplinary Scientific GeoConference-SGEM, pp. 215-221.

Molenda, M. and Ratman-Kłosińska, I. (2018). Quality assurance in environmental technology verification (ETV): Analysis and impact on the EU ETV pilot programme performance. Manage. Syst. Prod. Eng. vol. 26 iss. 1, pp. 49-54.

Nordin, N., Ashari, H. and Rajemi, M.F. (2014). A case study of sustainable manufacturing practices. J. Adv. Manag. Sci. 2, pp. 12-16.

Sujova, E. and Cierna, H. (2016). Parallels between corporate social responsibility and safety culture. Conference: International Scientific Days (ISD) Conference on Agri Food Value Chain Challenges for Natural Resources Management Society Location: Nitra, Slovakia, 19-20, pp. 288295.

Veleva, V. and Ellenbecker, M. (2001). Indicators of sustainable production: framework and methodology. J. Clean. Prod. 9, pp. 519-549. 